\title{
The Influence of Internal Control on Accrual Measure and Earnings Management
}

\author{
Chuyuan Huang ${ }^{1, \mathrm{a}^{*}}$, Mengnong Zhou ${ }^{2, \mathrm{~b}}$ and Jiayi Guan ${ }^{3, \mathrm{c}}$ \\ ${ }^{1}$ School of Business Administration, Wuhan University of technology, Hubei Wuhan 430070, China \\ ${ }^{2}$ Wuhan University of technology, Hubei Wuhan 430070, China \\ ${ }^{3}$ Wuhan University of technology, Hubei Wuhan 430070, China \\ cherry_huangcy@163.com ${ }^{\mathrm{a}}$, zhoumn2006@sina.com ${ }^{\mathrm{b}}$,guanjiayi@gaei.cn
}

Keywords: Internal control; Accrual measure; Earnings management; Internal control deficiencies

\begin{abstract}
This paper studies the internal control as the internal supervision mechanism of the enterprise, discusses its influence on earnings management with accrual measure of fair value between listed corporations with internal control deficiencies and without internal control deficiencies. The author examines the impact of internal control quality on accrual measure and earnings management through unpaired samples consisted of 1208 observations with internal control deficiencies and 3092 with perfect internal control from 2014 to 2016, based on the internal control of the listed company. The results indicate that listed companies usually adopt fair value of accrual measure as earning management tool, and internal control deficiency has influence on fair value and earnings management. The listed companies without internal control deficiency generally use investment income and assets impairment as earnings management tool, and those with internal control deficiency usually use extraordinary income as earnings management tool.
\end{abstract}

\section{Introduction}

Corporation governance's subjective motivations for earnings management manipulation are chasing economic and political interests. Some listed companies carry out Earnings Management with fair value. Wei indicated listed companies can be through non-operating revenue to adjust the earnings with analysis of 2010 - 2012 financial data in 129 cities in Shenzhen and Shanghai, but also show that the fair value had certain inhibitory effect on earnings management [1]. Wang found that AVIC used fair value measurement model manipulating the profits for earnings management through the case study of China Aviation Real Estate [2].

In this paper, from 2014 to 2016 A-share listed companies as the object of study, empirical study of internal control on the fair value and earnings management, found the use of fair value will increase the earnings management space; the existence of internal control deficiencies of the company and the absence of internal control Defective companies use the fair value of the means of earnings management. The main innovation is: in the study of the relationship between fair value and earnings management, through the existence of internal control defects on the sample group, from the internal control perspective as a starting point, the analysis of different internal control level of enterprises using the fair value of the means of earnings management.

\section{Theoretical Analysis and Research Hypothesis}

Fair value and earnings management. Rules 3, 22 and 23 affect the items in the income statement that include changes in the fair value of the gains and losses. There is a clear disclosure requirement for the valuation basis of the investment real estate, but the activity level of the market is not high, thus weakening the effect of information disclosure on the management of earnings management to a certain extent.

The reliability of fair value. Fair value determination method in the actual operation there is a certain degree of arbitrariness, asset impairment is likely to become a management tool to control the surplus. Based on this, assume that hypothesis 1: 
H1a: the use of fair value in financial assets is positively related to earnings management;

$\mathrm{H} 1 \mathrm{~b}$ : the use of fair value in asset impairment is positively related to earnings management;

H1c: The use of fair value in non-monetary asset exchange and debt restructuring is positively related to earnings management.

For listed companies with deficiencies in internal control, management is likely to use the traditional approach to asset impairment to achieve its purpose of adjusting earnings. In view of this, the hypothesis 2 :

$\mathrm{H} 2$ : There are deficiencies in internal controls and companies that do not have defects, and their means of using earnings at fair value are different.

\section{Research Design}

Measure of Earnings Management. In the empirical research on earnings management at home and abroad, the accrual profit separation method is usually used to obtain the accrual profit as the main measure of the level of accrual earnings management. The specific calculation method is as follows:

$N D A_{i, t}$ represents the estimated value of non-manipulative accrual profit, $\Delta \mathrm{REV}_{t}$ represents the difference between the main business income of year $t$ and year $t-1$, which represents the difference between net income of $\mathrm{t}$ year and $\mathrm{t}-1$ year, $P P E_{i, t}-1$ represents the net fixed assets of year $\mathrm{t} . \beta_{1}, \beta_{2}$ and $\beta_{3}$ can be obtained by the following formula:

$$
\frac{T A_{i, t}}{A_{i, t-1}}=\beta_{1} \times \frac{1}{A_{i, t-1}}+\beta_{2} \times \frac{\Delta R E V_{t}-\Delta R E C_{i, t}}{A_{i, t-1}}+\beta_{3} \times \frac{P P E_{i, t}}{A_{i, t-1}}+\varepsilon_{i, t}
$$

In order to avoid the positive and negative cancellation of the relevant earnings management, this paper uses the absolute value (Abs_DA) of the manipulative count to measure the degree of earnings management.

The construction of the model and the setting of variables. In order to test the relationship between the use of fair value and earnings management, this paper establishes the following model:

$$
\begin{aligned}
& A b s_{-} D A=\alpha_{1}+\alpha_{2} F V C+\alpha_{3} I N V E S F+\alpha_{4} I M P A I R+\alpha_{5} E X R E R+\alpha_{6} S I Z E+ \\
& \alpha_{7} L E V+\alpha_{8} R O A+\text { Yeareffect }+ \text { Industryeffect } \\
& A b s_{-} D A=\alpha_{1}+\alpha_{2} F V C+\alpha_{3} I N V E S F+\alpha_{4} I M P A I R+\alpha_{5} E X R E R+\alpha_{6} S I Z E+ \\
& \alpha_{7} L E V+\alpha_{8} R O A+\text { Yeareffect }+ \text { Industryeffect } \quad \text { (if ICA =1) } \\
& A b s_{-} D A=\alpha_{1}+\alpha_{2} F V C+\alpha_{3} I N V E S F+\alpha_{4} I M P A I R+\alpha_{5} E X R E R+\alpha_{6} S I Z E+ \\
& \left.\alpha_{7} L E V+\alpha_{8} R O A+\text { Yeareffect }+ \text { Industryeffect } \quad \text { (if ICA }=0\right)
\end{aligned}
$$

Among them, FVC, INVEST, IMPAIR, EXREV said that the fair value of listed companies use four accounting accounts: fair value gains and losses, investment income, asset impairment and non-operating income. 
Table 1 Variable Definition Table

\begin{tabular}{|c|c|c|}
\hline $\begin{array}{l}\text { Variable } \\
\text { category }\end{array}$ & Variable name & Variable description \\
\hline $\begin{array}{l}\text { Explained } \\
\text { variable }\end{array}$ & Abs_DA & Handling accruals \\
\hline \multirow{4}{*}{$\begin{array}{l}\text { Explanatory } \\
\text { variables }\end{array}$} & FV & $\begin{array}{l}\text { Variable profit and loss of fair value / total } \\
\text { assets at the beginning of the period, measure } \\
\text { the fair value }\end{array}$ \\
\hline & INVEST & $\begin{array}{l}\text { Investment income / total assets at the } \\
\text { beginning of the period, measure the use of } \\
\text { fair value }\end{array}$ \\
\hline & IMPAIR & $\begin{array}{c}\text { Asset impairment / total assets at the } \\
\text { beginning of the period, measure fair value } \\
\text { utilization degree }\end{array}$ \\
\hline & EXREV & $\begin{array}{l}\text { Extra revenue / total assets at the beginning of } \\
\text { the period, measure the fair value of the use } \\
\text { degree }\end{array}$ \\
\hline \multirow{5}{*}{ Control variable } & SIZE & Company Size \\
\hline & LEV & Asset-liability ratio \\
\hline & ROA & Return on assets \\
\hline & Yeareffect & Year dummy variable \\
\hline & Industyeffect & Industry dumb variable \\
\hline
\end{tabular}

\section{sample selection and descriptive statistics}

Sample selection and data sources. This paper selects the A-share listed companies from 2014 to 2016 as the object of study, and removes the following samples: listed companies in the financial sector; ST, * ST listed companies; cross-listed companies; annual observation of less than ten observations; data dissatisfaction Four years missing samples. And finally get 4300 sample data. The financial data of this paper are from the Guotai CSMAR database. The measurement software used in this article is STATA14.0.

Table 2 Sample Slection

\begin{tabular}{cc}
\hline Sample screening step & Total \\
\hline Total number of A shares listed companies & 8670 \\
Less: Financial listed companies & 205 \\
Less: ST, * ST listed companies & 520 \\
Less: Cross listed (B or H) listed companies & 775 \\
Less: the industry observed less than forty & 0 \\
Less: missing company or company with less than four years of & 2870 \\
Total number of samples & 4300 \\
Where: number of samples with internal control deficiencies & 1208 \\
number of samples of without internal control deficiencies & 3092 \\
\hline
\end{tabular}

Descriptive statistics. From Table 3, it can be found that the average value of earnings management is 0.13040 , the minimum and maximum values are 0.00005 and 1.17176 respectively, which indicates that the phenomenon of earnings management of listed companies is prevalent, but the earnings management of different listed companies the extent of the existence of great differences. 
Table 3 Total Sample Descriptive Statistics

\begin{tabular}{cccccccc}
\hline $\begin{array}{c}\text { Varia } \\
\text { ble }\end{array}$ & $\begin{array}{c}\text { Minim } \\
\text { um }\end{array}$ & $\begin{array}{c}25 \% \\
\text { of the } \\
\text { quantiles }\end{array}$ & $\begin{array}{c}\text { Media } \\
\mathrm{n}\end{array}$ & Mean & $\begin{array}{c}75 \% \\
\text { of the } \\
\text { quantiles }\end{array}$ & $\begin{array}{c}\text { Maxim } \\
\text { um }\end{array}$ & $\begin{array}{c}\text { Standa } \\
\text { rd } \\
\text { Deviation }\end{array}$ \\
\hline Abs - & 0.0000 & 0.029 & 0.068 & 0.130 & 0.135 & 1.1717 & 0.1946 \\
DA & 5 & 81 & 18 & 40 & 00 & 6 & 2 \\
& -0.096 & 0.000 & 0.000 & 0.000 & 0.000 & 0.1810 & 0.0055 \\
FV & 93 & 00 & 00 & 20 & 00 & 4 & 7 \\
INV & -0.127 & 0.000 & 0.001 & 0.011 & 0.008 & 1.3173 & 0.0402 \\
EST & 72 & 00 & 33 & 30 & 82 & 1 & 4 \\
IMP & -0.204 & 0.000 & 0.002 & 0.006 & 0.007 & 0.4745 & 0.0199 \\
AIR & 78 & 44 & 62 & 43 & 23 & 0 & 6 \\
EXR & 0.0000 & 0.001 & 0.005 & 0.015 & 0.011 & 3.2572 & 0.0824 \\
EV & 0 & 92 & 05 & 30 & 98 & 9 & 3 \\
& 18.181 & 20.98 & 21.76 & 21.84 & 22.61 & 26.487 & 1.2000 \\
SIZE & 23 & 985 & 971 & 978 & 547 & 20 & 1 \\
LEV & 0.0070 & 0.365 & 0.519 & 0.519 & 0.665 & 7.0023 & 0.2790 \\
& 8 & 96 & 00 & 32 & 08 & 4 & 1 \\
ROA & -0.182 & 0.003 & 0.015 & 0.022 & 0.035 & 0.7427 & 0.0376 \\
\hline & 92 & 59 & 53 & 53 & 49 & 9 & 0 \\
\hline
\end{tabular}

\section{Research Results and Analysis}

Table 4 shows that the overall view, the existence of listed companies using the fair value of earnings management behavior, support the $\mathrm{H} 1 \mathrm{a}, \mathrm{H} 1 \mathrm{~b}, \mathrm{H} 1 \mathrm{c}$. Table 6 shows the results of dividing the samples into groups with internal control flaws and no internal control flaws. There are significant differences in the use of fair value between the two types of listed companies and the level of earnings management. In summary, there are significant positive correlations between non-operating income and earnings management, and there are significant positive correlations between investment income and non-operating income and earnings management, and $\mathrm{H} 2$ has been proved.

Table 4 Regression Coefficient Statistics Table

\begin{tabular}{ccccc}
\hline Variable & $\begin{array}{c}\text { Expected } \\
\text { symbol }\end{array}$ & $\begin{array}{c}\text { Without internal } \\
\text { control deficiencies }\end{array}$ & $\begin{array}{c}\text { Expected } \\
\text { symbol }\end{array}$ & $\begin{array}{c}\text { With internal } \\
\text { control } \\
\text { deficiencies }\end{array}$ \\
\hline FVC & + & .4571741 & 0.90 & 0.368 \\
INVEST & + & $.1856061^{* * *}$ & 2.60 & 0.009 \\
IMPAIR & + & $.4750971^{* * *}$ & 3.24 & 0.001 \\
EXREV & + & $.0840635^{* *}$ & 2.38 & 0.017 \\
SIZE & - & $-.0469053^{* * *}$ & -18.07 & 0.000 \\
LEV & - & -.0023618 & -0.21 & 0.834 \\
ROA & + & $.311727^{* * *}$ & 3.66 & 0.000 \\
\hline Yeareffect & & & & Control \\
Industyeffect & & & & Control \\
\hline R2 & & & & $10.45 \%$ \\
Adj. R2 & & & & 23.78 \\
F & & & & 4300 \\
Obs. No & & & &
\end{tabular}


Table 5 Group Regression Coefficient Statistics Table

\begin{tabular}{|c|c|c|c|c|}
\hline Variable & $\begin{array}{l}\text { Expected } \\
\text { symbol }\end{array}$ & $\begin{array}{l}\text { Without internal } \\
\text { control deficiencies }\end{array}$ & $\begin{array}{c}\text { Expected } \\
\text { symbol }\end{array}$ & $\begin{array}{c}\text { With internal } \\
\text { control } \\
\text { deficiencies }\end{array}$ \\
\hline FVC & + & $\begin{array}{c}.4132596 \\
0.58\end{array}$ & + & $\begin{array}{c}.5947538 \\
0.77\end{array}$ \\
\hline INVEST & + & $\begin{array}{c}.3043572 * * * \\
3.13\end{array}$ & + & $\begin{array}{c}.0638932 \\
0.56\end{array}$ \\
\hline IMPAIR & + & $\begin{array}{c}.2104416 \\
1.00\end{array}$ & + & $\begin{array}{c}532497 * * \\
2.39\end{array}$ \\
\hline EXREV & + & $\begin{array}{c}.1079118 * * \\
2.16\end{array}$ & + & $\begin{array}{c}.0628023 \\
1.12\end{array}$ \\
\hline SIZE & - & $\begin{array}{c}-.0398155^{* * *} * \\
-12.98 \\
-.0264251\end{array}$ & - & $\begin{array}{c}-.0587509 * * * \\
-10.09 \\
.0101212\end{array}$ \\
\hline LEV & - & - 1.62 & - & 0.57 \\
\hline ROA & + & $\begin{array}{c}.4107742 * * * \\
3.96\end{array}$ & + & $\begin{array}{c}.2198817 \\
1.34\end{array}$ \\
\hline Yeareffect & & Control & & Control \\
\hline Industyeffect & & Control & & Control \\
\hline R2 & & $9.74 \%$ & & $13.76 \%$ \\
\hline Adj. R2 & & $9.30 \%$ & & $12.24 \%$ \\
\hline $\mathrm{F}$ & & 21.98 & & 9.01 \\
\hline Obs. No & & 4300 & & 1208 \\
\hline
\end{tabular}

\section{Research Conclusions and Policy Recommendations}

Listed companies have the use of fair value for earnings management behavior. Good internal control does not regulate and control the return on investment and non-operating income, both of which still show a significant positive correlation with earnings management. In contrast, there is a significant positive correlation between asset impairment and earnings management, and there is still a positive correlation between investment income and non-operating income and earnings management level, but it is not significant. This shows that there are deficiencies in the internal control of listed companies are more willing to choose other means of asset impairment losses as a means of earnings management.

Increase the disclosure of fair value in the Accounting Standards for Business Enterprises. Improve the internal control of the internal control system of fair value related to the internal control. Therefore, to improve the internal control system of internal control of financial assets in the relevant laws and regulations and guidelines need to be resolved. To improve the internal control of financial assets, and to improve the internal control of financial assets, and to improve the relevant regulations on the evaluation of internal control of fair value of financial assets and improve the relevant regulations on the internal control of financial assets. Institutions to understand the level of internal control of listed companies, to carry out related work better.

\section{References}

[1] Wei T. Motivation, Means and Effects of Non-recurring Profit and Earnings Management Empirical Evidence from Chinese Listed Companies [J]. Management World. (2007).

[2] Wang Y. The impact of fair value measurement on earnings management - Taking AVIC as an example [J]. Financial Accounting, 07: 30-32. (2017).

[3] HUANG M., XIA X.P. Experimental Analysis of Earnings Management Capability by 
Maneuvering Accrual Profit Model [J]. Nankai Management Review.

[4] Kothari, S., A. Leone, C. Wasley.. Performance with discretionally accrual measures [J]. Journal of Accounting and Economics, 39: 163-197. (2005)

[5] Lin Y.J. etc. Executive change and earnings management -based on accrual project manipulation and real activity manipulation of empirical research [J]. Nankai Management Review. (2013).

[6] Li W.F., etc. The role of internal control in corporate investment: efficiency promotion or suppression [J]. Management World. (2011).

[7] Wu S.P., Fu S.H. Impact of Voluntary Audit and Fair Value on Earnings Management Empirical Data Based on Interim Report of Listed Companies in 2006-2007 [J]. Financial Research. (2009).

[8] $\mathrm{Wu} \mathrm{L}$. Based on the fair value of the earnings management research [J]. Financial Accounting, 11: 7-10. (2014).

[9] Ye J.F. et al. The Impact of Internal Control Defects and Their Amendments on Earnings Management [J]. Auditing Research. (2012).

[10] Xie D. Accounting Standards, Capital Market Regulation and Earnings Management: Evidence from Debt Restructuring of Listed Companies [J]. Accounting Research. (2011). 